\title{
Cercariae (Digenea: Strigeidae, Diplostomidae) in Biomphalaria straminea (Planorbidae) from a rice field in Northeastern Argentina
}

\author{
María Virginia Fernández* \& Monika Inés Hamann \\ Consejo Nacional de Investigaciones Científicas y Técnicas (CONICET). Centro de Ecología Aplicada del Litoral \\ (CECOAL), Ruta 5 Km 2.5, W 3400 AMD, Corrientes, Argentina; mvirginiafernandez@yahoo.com.ar, \\ monika_hamann@yahoo.com
}

Received 01-VI-2016. Corrected 07-XI-2016. Accepted 06-XII-2016.

\begin{abstract}
The rice fields can provide habitats for many species of aquatic invertebrates, as insects, molluscs, crustaceans; and vertebrates, as fish, amphibians, reptiles and birds, which may act as hosts in the life cycles of digenean parasites. In this context, the goal of the present study was to describe the cercariae found in Biomphalaria straminea from a rice field in Northeastern Argentina. This freshwater snail inhabits a wide variety of environments, favoring shallow, temporary and standing or slow-flowing freshwater bodies. For this study, snails were collected from the cultivated parcels and irrigated channels during the flooding periods (from the time of sowing to soon after harvesting of the rice) between December 2010 and May 2011 and December 2011 and April 2012, in a rice field from Corrientes province, one of the main rice producers of Argentina. A total of 5510 snails were examined of which 26 were infected with three different larval trematodes belonging to Strigeidae, Furcocercaria V $(0.40 \%)$ and Furcocercaria XX (0.04 \%), and Diplostomidae, Furcocercaria XIX $(0.04 \%)$. Furcocercaria XX and Furcocercaria XIX were present in one rice cultivation cycle, while Furcocercaria $\mathrm{V}$ was present in both rice cultivation cycles. The prevalence of the different furcocercariae was somewhat higher in the second rice cultivation cycle. The cercariae described are new records for Argentina that added to 53 cercariae previously reported for Biomphalaria spp. in different aquatic environments of country. The study of the digenean larval in rice fields is important because contribute to the knowledge of the biodiversity of these environments. Rev. Biol. Trop. 65 (2): 551-563. Epub 2017 June 01.
\end{abstract}

Key words: Trematoda, freshwater snails, larval stages, agricultural wetlands, Corrientes province.

The rice fields act as temporary artificial wetlands (Ramsar Convention 2011; http:// www.ramsar.org) due to the alternating periods of flooding in summer and drought in winter. Worldwide, several studies have demonstrated its importance in biological conservation, since can improve habitats for many species of aquatic invertebrates, as insects, molluscs, crustaceans; and vertebrates, as fish, amphibians, reptiles and birds (Bambaradeniya, 2000; Czech \& Parsons, 2002; Bambaradeniya \& Amerasinghe, 2003; Manley, 2008; Elphick, Parsins, Fasola, \& Mugica, 2010). In the Neotropical region, different studies have been carried out about the biodiversity of macroinvertebrates, amphibians, birds and macrophytes in the irrigated channels of rice fields (Blanco, López-Lanús, Dias, Azpiroz, \& Rilla, 2006; Stenert, Bacca, Maltchik, \& Rocha, 2009; Machado \& Maltchik, 2010; Maltchik, Rolon, Stenert, Machado, \& Rocha, 2011). Specifically in Northeastern Argentina, the macroinvertebrates, planorbids, amphibians, fish and birds diversity has been the subject of studies in rice fields (Rumi \& Hamann, 1990; Duré, Kehr, Schaefer, \& Marangoni, 2008; Blanco \& de la Balze, 2011). However, the larval trematodes that infect molluscs in these temporary 
artificial wetlands were little studied (Fernández, Hamann, \& Ostrowski de Núñez, 2013, 2014). The fact that the presence of larval trematodes provides indirect information about occurrence of their hosts highlights the importance of their study to contribute to the knowledge of the biodiversity in these environments.

The species of Biomphalaria Preston, 1910 (Gastropoda: Planorbidae) are widely distributed in Argentina, mainly in the Northeast (Rumi \& Núñez, 2013). In particular, Biomphalaria straminea (Dunker, 1848) is more restricted to the Northeast and pampean regions, being very frequent in the Río de La Plata basin, namely in the Paraná and Uruguay rivers (Núñez, Gutierrez Gregoric, \& Rumi, 2010; Rumi \& Núñez, 2013). This species, natural vector of Schistosoma mansoni Sambon, 1907 in Brazil, inhabits a wide variety of environments, favoring shallow, temporary and standing or slow-flowing freshwater bodies. Thus, rice fields provide favorable conditions for the development of dense populations of this planorbid snail.

In Argentina, the larval trematodes diversity of Biomphalaria species, have been studied mainly in natural environments. Recently, Fernández et al. $(2013,2014)$ described larval trematodes in B. straminea from a rice field in Corrientes province, Argentina, one of the main rice producers of Argentina (ACPA, 2014). In this context, the goal of the present work was to complete the description of the cercariae found in the sampling of molluscs of this environment. We provide descriptions of new larval trematodes and assign them to taxonomic families and genera. In some cases, we add data about the period of emergence of cercariae and potential second intermediate hosts, and information about their prevalence.

\section{MATERIALS AND METHODS}

The study site was an agricultural area with cultivated rice parcels connected or associated to the Paraná river basin, located approximately $30 \mathrm{~km}$ South from Corrientes city, in Corrientes province, Argentina $\left(27^{\circ} 40^{\prime} \mathrm{N}\right.$ - 58०48'21.6” W).

Snails were collected during the flooding periods ( $\mathrm{n}=5$ 510), from the time of sowing to soon after harvesting of the rice, between December 2010 and May $2011(\mathrm{n}=3$ 494), and December 2011 and April $2012(\mathrm{n}=2$ 016). Samples were taken manually from the border of cultivated parcels and irrigated channels. Two persons sampled in the morning during 1.5 hours, using simple mesh nets, locally named "copos" (25 cm frame diameter). The width of the studied channels $(n=2)$ was approximately $2 \mathrm{~m}$, and $260 \mathrm{~m}$ in length. In the laboratory, the snails were kept individually in vials with $20 \mathrm{~mL}$ of tap water, and were observed for the emergence of cercariae. Seemingly uninfected snails were dissected to check for other larval intramolluscan stages (e.g. immature infections and metacercariae).

Cercariae were studied alive, with and without vital dyes $(0.01 \%$ aqueous solutions of neutral red and Nile blue sulphat). Drawings were made using a camera lucida attached to a Carl Zeiss Jena microscope. Measurements given in the description of each cercaria are based on heat-killed and formalin-fixed specimens and expressed in micrometers $(\mu \mathrm{m})$, with range followed by the mean $\pm \mathrm{SD}$ in parentheses. We adopted the "open nomenclature" recommended by Odening (1971) for new species of cercariae. Cercariae fixed in hot $4 \%$ formalin were preserved in vials with $70 \%$ ethanol, and deposited in the Helminthological Collection of the Centro de Ecología Aplicada del Litoral (CECOAL), Corrientes, Argentina.

Photographs were taken with a Leica DFC 295 camera mounted on a Leica DM 2500 microscope. Specimens to be studied by scanning electron microscopy (SEM) were dehydrated in an ethanol series, dried using the critical point technique, coated with goldpalladium and examined under a Jeol $5800 \mathrm{LV}$ Scanning Electron Microscope.

To determine the second intermediate host, laboratory-reared Cnesterodon sp. were exposed to the emerged cercariae. The fish were maintained in small aquaria under controlled 
conditions until dissection, which was carried out five hours post-exposure (PE). Overall prevalence of each trematode taxon and prevalence in each season was calculated following Bush, Lafferty, Lotz and Shostak (1997).

\section{RESULTS}

A total of 26 snails were infected with the cercariae here described. The prevalence of individual larval trematodes was lower than $1 \%$; Furcocercaria XX and Furcocercaria XIX were present in one rice cultivation cycle, while Furcocercaria $\mathrm{V}$ was present in both rice cultivation cycles, with higher prevalence in the second rice cultivation cycle (Fig. 1). The cercariae described are added to 53 previously reported for Biomphalaria spp. in different aquatic environments of Argentina (Table 1).

\section{Superfamily Diplostomoidea Poirier, 1886 Family Diplostomidae Poirier, 1886 \\ Furcocercaria XIX (Figs. 2-4, 12-13) \\ Prevalence: $0.04 \%$}

Specimen deposited: accession number CECOAL 11031417

Description: Measurements based on ten

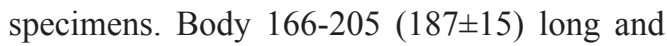
44-62 (54 \pm 6$)$ wide. Tegument covered with large spines distributed in 9-10 transverse rows between anterior organ and ventral sucker, posterior spines smaller and scattered in lateral fields. One pair of sensory hairs at level of excretory vesicle. Anterior organ elongate-

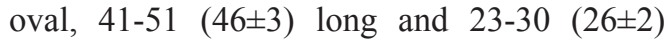
wide, first third covered with 9-10 rows of spines followed by short spineless area. Prepharynx shorter than pharynx, pharynx oval, 10-17 (14 \pm 2$)$ long and 10-14 (13 \pm 1$)$ wide. Oesophagus shorter than pharynx, intestinal bifurcation in posterior third of forebody; caeca becoming wider in hindbody and terminate fairly close to excretory vesicle. Ventral sucker subspherical, post-equatorial, 28-32 (29 \pm 2$)$ long and 30-34 (33 \pm 2 ) wide, with 2-3 circles of hooks surrounding its opening. Four big penetration gland-cells coarsely granulated situated anterior to ventral sucker: two glands situated one behind the other between the bifurcation of the esophagus and the ventral sucker, and the other two glands larger, one on either side of the ventral sucker. Flame cell formula: $2[(2+2)+(2+2+[2])]=20$. Excretory vesicle small, $\mathrm{V}$-shaped. Caudal excretory duct passes through tail stem, excretory pores at mid-length of furcae. Tail stem 170-198 $(183 \pm 11)$ long and 34-44 (39 \pm 3$)$ wide, with four pairs of caudal bodies and several pairs of

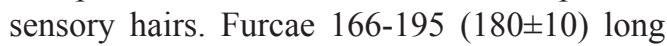
and 16-28 (23 \pm 3$)$ wide.

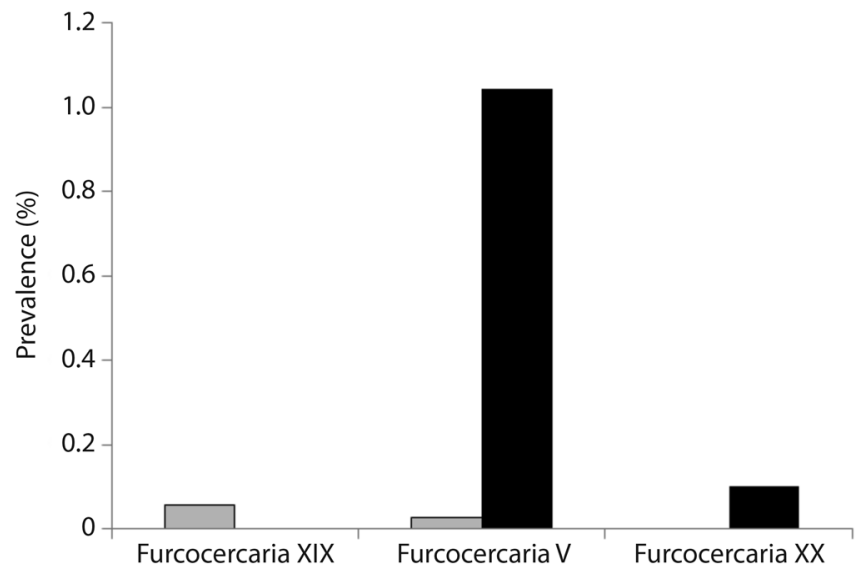

Fig. 1. Prevalence of larval trematode infections in $B$. straminea from a rice field in Corrientes province during 2 rice cultivation cycles, gray bar: December 2010 - May 2011 ( $n=$ number of collected snails: 3 494); black bar: December 2011May $2012(\mathrm{n}=2$ 016). 
TABLE 1

Previous records of larval trematodes infecting Biomphalaria species in different environments of Argentina

\begin{tabular}{|c|c|c|c|c|}
\hline Larval Trematodes & Hosts * & $\mathrm{E}^{* *}$ & Locality & References \\
\hline Furcocercaria sp. I & $\mathrm{BS}$ & LW & Corrientes & $\begin{array}{l}\text { Ostrowski de Núñez, Hamann, } \\
\text { \& Rumi, } 1990\end{array}$ \\
\hline Furcocercaria sp. III & $\mathrm{BO}$ & SP & Corrientes & $\begin{array}{l}\text { Ostrowski de Núñez, Hamann, \& } \\
\text { Rumi, 1997, Fernández, Hamann, } \\
\text { \& Ostrowski de Núñez, } 2016\end{array}$ \\
\hline Furcocercaria V & BS & $\mathrm{RF}$ & Corrientes & Present study \\
\hline Furcocercaria sp. VIII & BP, BOR & SP & Corrientes & Ostrowski de Núñez et al., 1997 \\
\hline Furcocercaria sp. X & BOR & SP & Corrientes & Ostrowski de Núñez et al., 1997 \\
\hline Furcocercaria sp. XIII & BT, BOR & SP & Corrientes & Ostrowski de Núñez et al., 1997 \\
\hline Furcocercaria sp. XIV & BS & $\mathrm{RF}$ & Corrientes & Fernández et al., 2013 \\
\hline Furcocercaria sp. XV & BS & $\mathrm{RF}$ & Corrientes & Fernández et al., 2013 \\
\hline Furcocercaria sp. XVI & BS & $\mathrm{RF}$ & Corrientes & Fernández et al., 2013 \\
\hline Furcocercaria sp. XVII & $\mathrm{BS}$ & $\mathrm{RF}$ & Corrientes & Fernández et al., 2013 \\
\hline Furcocercaria sp. XVIII & BS & $\mathrm{RF}$ & Corrientes & Fernández et al., 2013 \\
\hline Furcocercaria XIX & $\mathrm{BS}$ & $\mathrm{RF}$ & Corrientes & Present study \\
\hline Furcocercaria XX & $\mathrm{BS}$ & $\mathrm{RF}$ & Corrientes & Present study \\
\hline Furcocercaria I & $\mathrm{BP}$ & $\mathrm{S}$ & Buenos Aires & Ostrowski de Núñez, 1972 \\
\hline Furcocercaria V & $\mathrm{BP}$ & TW & Buenos Aires & Ostrowski de Núñez, 1977 \\
\hline Furcocercaria VI & $\mathrm{BP}$ & TW & Buenos Aires & Ostrowski de Núñez, 1977 \\
\hline Cercaria planorbicola n. sp. & $\mathrm{BP}$ & $\mathrm{R}$ & Buenos Aires & Szidat \& de Szidat, 1960 \\
\hline Australapatemon magnacetabulum & BT & TW & Salta & $\begin{array}{l}\text { Davies \& Ostrowski } \\
\text { de Núñez, } 2012\end{array}$ \\
\hline Strigea sp. & BT & TW & Salta & Davies, 2014 \\
\hline Cercaria Spirorchiidae sp. & BT, BO & SP & Corrientes & Fernández et al., 2016 \\
\hline Cercaria Clinostomidae sp. & $\mathrm{BO}$ & SP & Corrientes & Fernández et al., 2016 \\
\hline Clinostomum sp. & BT & TW & Salta & Davies, 2014 \\
\hline Cf. Trichobilharzia sp. & $\mathrm{BT}$ & TW & Salta & Davies, 2014 \\
\hline Furcocercaria sp. 6 & $\mathrm{BT}$ & TW & Salta & Davies, 2014 \\
\hline Cercaria quequeni n. sp. & $\mathrm{BP}$ & $\mathrm{R}$ & Buenos Aires & Szidat, 1951 \\
\hline Echinocercaria sp. II & BS & TW & Corrientes & Ostrowski de Núñez et al., 1990 \\
\hline Echinocercaria sp. III & $\mathrm{BO}$ & SP & Corrientes & $\begin{array}{l}\text { Ostrowski de Núñez, Hamann, } \\
\text { \& Rumi, } 1991\end{array}$ \\
\hline Echinocercaria sp. IV & $\begin{array}{l}\mathrm{BO}, \mathrm{BT}, \mathrm{BS}, \\
\mathrm{BP}, \mathrm{BOR}\end{array}$ & SP & Corrientes & $\begin{array}{l}\text { Ostrowski de Núñez et al., } 1997, \\
\text { Fernández et al., } 2016\end{array}$ \\
\hline Echinocercaria sp. V & BOR & SP & Corrientes & Ostrowski de Núñez et al., 1997 \\
\hline Echinocercaria sp. VII & $\mathrm{BO}$ & SP & Corrientes & Ostrowski de Núñez et al., 1991 \\
\hline Cercaria Ribeiroia sp. & $\mathrm{BO}$ & SP & Corrientes & $\begin{array}{l}\text { Ostrowski de Núñez et al., 1991, } \\
\text { Fernández et al., } 2016\end{array}$ \\
\hline Ribeiroia sp. & BOR, BT & $\mathrm{D}$ & Salta & Davies, 2014 \\
\hline Cercaria Echinostoma $\mathrm{N}^{\circ} 3$ & $\mathrm{BT}$ & $\mathrm{S}$ & Corrientes & $\begin{array}{l}\text { Martorelli, Alda, Marcotegui, } \\
\text { La Sala, \& Montes, } 2013\end{array}$ \\
\hline Cercaria Monostoma No 1 & BT & $\mathrm{R}$ & Corrientes & Martorelli et al., 2013 \\
\hline Cercaria Macrogranulosa & $\mathrm{BS}, \mathrm{BP}, \mathrm{BOR}$ & LW,R & Corrientes & Ostrowski de Núñez et al., 1990 \\
\hline Echinocercaria sp. XIII & $\mathrm{BS}$ & $\mathrm{RF}$ & Corrientes & Fernández et al., 2014 \\
\hline Echinocercaria sp. XIV & $\mathrm{BS}, \mathrm{BO}$ & RF, SP & Corrientes & Fernández et al., 2014, 2016 \\
\hline Echinocercaria sp. XVI & BS & $\mathrm{RF}$ & Corrientes & Fernández et al., 2014 \\
\hline Echinocercaria sp. 1 & $\mathrm{BO}, \mathrm{BT}$ & SP & Corrientes & Fernández et al., 2016 \\
\hline
\end{tabular}


TABLE 1 (Continued)

\begin{tabular}{lllll} 
Larval Trematodes & Hosts * & E** & Locality & References \\
Echinocercaria sp. 2 & BO & SP & Corrientes & Fernández et al., 2016 \\
Echinocercaria sp. 3 & BT, BO & SP & Corrientes & Fernández et al., 2016 \\
Echinocercaria I & BP & D, SP & Córdoba, Buenos Aires & Ostrowski de Núñez, 1981 \\
Episthmium suspensum & BP & S & Buenos Aires & Ostrowski de Núñez, 1974a \\
Petasiger sp. & BT, BOR & D & Salta & Davies, 2014 \\
Echinocercaria sp. 1 & BT & D & Salta & Davies, 2014 \\
Echinocercaria sp. 3 & BT & LW & Salta & Davies, 2014 \\
Zygocotyle lunata & BP, BT & P & Buenos Aires, Salta & Ostrowski de Núñez, Davies, \\
& & & & \& Spatz, 2011 \\
Magnivitellinum simplex & BOR, BT & TW & Salta & Davies, 2014 \\
Notocotylus biomphalariae $n$. sp. & BP & P & Rio Negro & Flores \& Brugni, 2005. \\
Hippocrepis fuelleborni & BP & TW & Buenos Aires & Ostrowski de Núñez, 1976 \\
Xiphidiocercaria sp. I & BS, BP, BOR & R, TW & Corrientes & Ostrowski de Núñez et al., 1990 \\
Xiphidiocercaria sp. II & BS & TW & Corrientes & Ostrowski de Núñez et al., 1990 \\
Xiphidiocercaria sp. V & BO & SP & Corrientes & Ostrowski de Núñez et al., 1991 \\
Xiphidiocercaria A & BP & S & Buenos Aires & Morris, 1976 \\
Xiphidiocercaria B & BP & S & Buenos Aires & Morris, 1976 \\
Xiphidiocercaria sp. 1 & BP & TW & Buenos Aires & Ostrowski de Núñez, 1974b. \\
Xiphidiocercaria sp. 2 & BT & TW & Salta & Davies, 2014 \\
\hline
\end{tabular}

* Hosts: BT, B. tenagophila; BO, B. occidentalis; BOR, B. orbignyi; BP, B. peregrina; BS, B. straminea.

** Environments (E): RF, rice field; SP, semipermanent ponds; P, pond; LW, lotic waterbodies; TW, temporary waterbody; $\mathrm{D}$, dam; R, river; $\mathrm{S}$, stream.

Cercariae emerge from sporocysts. At resting position, the cercariae maintained themselves suspended in water with their bodies bent at a characteristic angle, tail stem straight, and furcae spread at an angle of more than $90^{\circ}$ (Fig. 4).

Emerged cercariae penetrated in exposed Cnesterodon sp. Five hours post-exposure (PE) the fish were dissected, showing many free young metacercariae, not yet encysted in the body musculature.

Remarks: Cercariae with four penetration gland-cells (two anterior and two lateral to the ventral sucker), 20 flame cells and absent eyespots have been described in the genus Hysteromorpha Lutz, 1931. These cercariae penetrate primarily into fishes and their definitive hosts are mainly aquatic birds of the families Phalacrocoracidae and Ardeidae and genus Burhinus (Niewiadomska, 2005). Hugghins (1954) described the life cycle of Hysteromorpha triloba (Rudolphi, 1819) whose cercaria is similar to Furcocercaria XIX in the morphology of the penetration gland cells, presence of three circles of spines surrounding the opening of the ventral sucker, number and position of sensory hairs on the body (one pair) and several pairs in the tail stem, resting position, size of the body (168-221/41-50 H. triloba vs. 166-205/44-62 Furcocercaria XIX) and anterior organ (42$53 / 20-28$ vs. $41-51 / 23-30$ ), by penetrating into fishes. However, Furcocercaria XIX differs in the arrangement of the penetration gland-cells (anterior to ventral sucker), the presence of caudal bodies, shorter tail stem (170-198/3444 Furcocercaria XIX vs. 226-260/28-42 $H$. triloba) and furcae (165-195 vs. 196-227), and larger ventral sucker (30-34 vs. 17-20).

In Argentina, two cercariae have been reported that could be comparable to Furcocercaria XIX in number and arrangement of the penetration gland-cells: Furcocercaria sp. A (cf. Tylodelphys sp.) Ostrowski de Núñez 

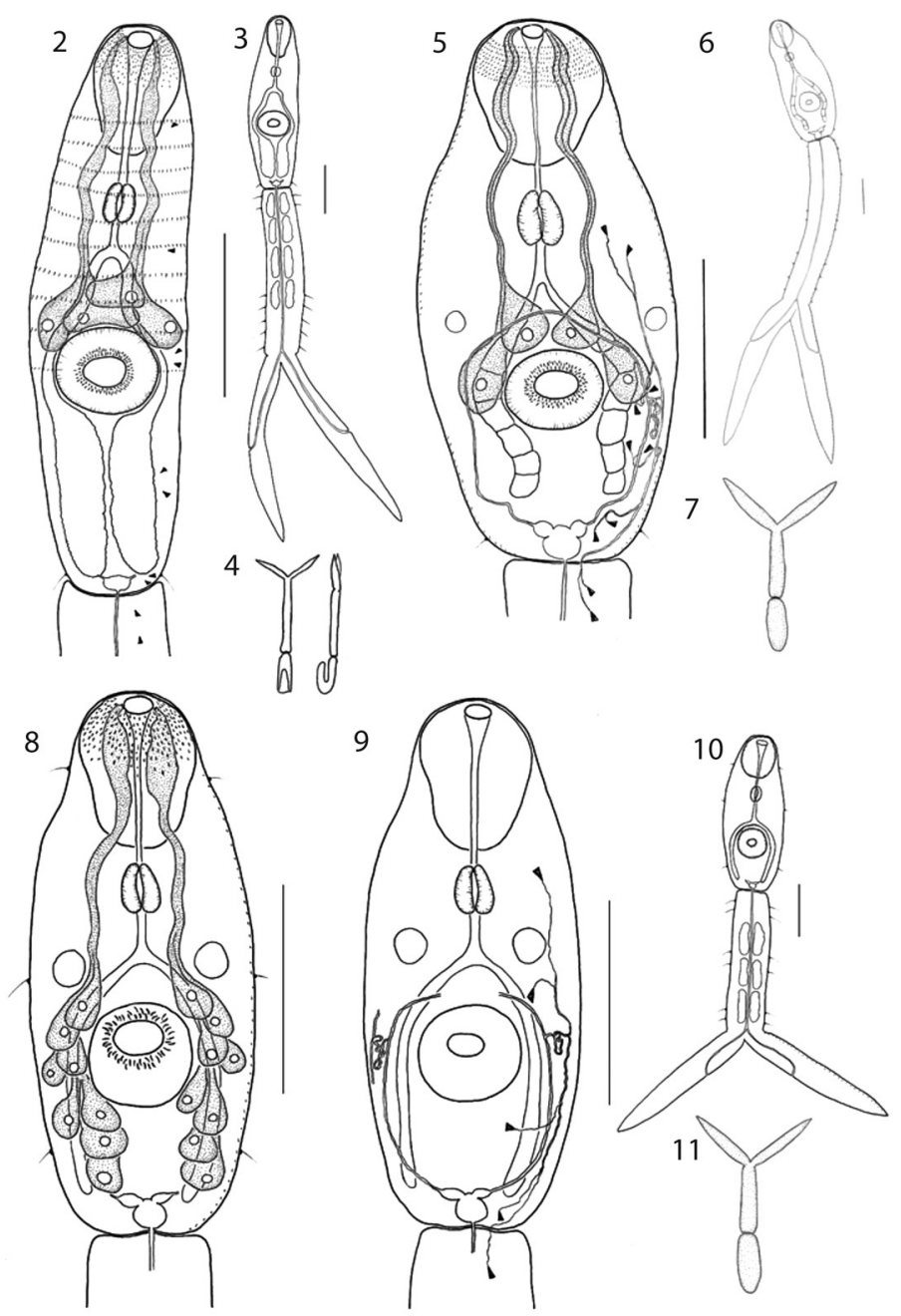

Figs. 2-11. Line drawings of larval trematodes. 2-4: Furcocercaria XIX (2: cercarial body, 3: cercaria and tail in ventral view, 4: resting position); 5-7: Furcocercaria V (5: cercarial body, 6: cercaria and tail in ventral view; 7: resting position); 8-11: Furcocercaria XX (8: cercarial body in ventral view, showing the penetration gland-cells, 9: cercarial body in ventral view, showing the excretory system, 10: cercaria and tail in ventral view, 11: resting position). Scale bars: $50 \mu \mathrm{m}$.

\& Quaggiotto, 1995 from Chilina sp. of Río Negro province and Austrodiplostomum mordax Szidat \& Nani, 1951 from B. peregrina of Buenos Aires. However, both cercariae differ from Furcocercaria XIX in having fewer flame cells (16), more caudal bodies (five pairs), fewer circles of hooks surrounding the opening of the ventral sucker (one circle of hooks), and different arrangement of spines in the body.

In Belo Horizonte, Minas Gerais, Brazil Pinto (2013) described the cercaria of
$H$. triloba parasitizing $B$. straminea, which is similar to Furcocercaria XIX in the morphology of penetration gland-cells, resting position in water and size of the anterior organ (3358/23-28 H. triloba vs. 41-51/23-30 Furcocercaria XIX). However, the cercaria of $H$. triloba differs from Furcocercaria XIX in the arrangement of the penetration gland-cells (one pair anterior and one pair lateral to the ventral sucker), the absence of caudal bodies in tail stem, smaller body $(175 \pm 15 / 44 \pm 4$ vs. $187 \pm 15 / 54 \pm 6)$ 

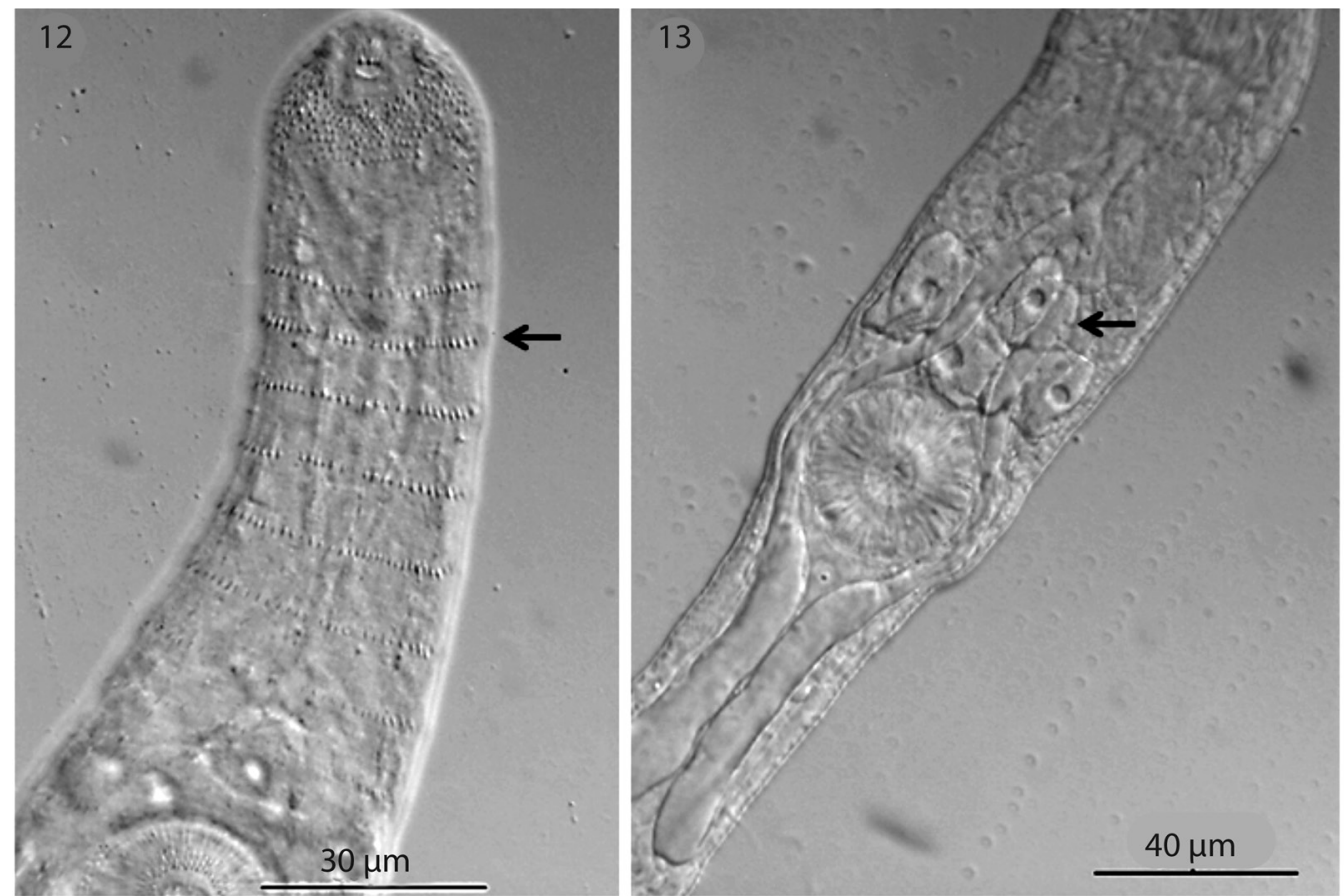

Figs. 12-13. Light micrographs of Furcocercaria XIX. 12: cercarial body showing tegument covered with large spines distributed in 9-10 transverse rows between anterior organ and ventral sucker; 13: cercarial body showing the penetration gland-cells.

and ventral sucker $(18 \pm 1 / 18 \pm 2$ vs. $29 \pm 2 / 33 \pm 2)$, larger tail stem $(236 \pm 16 / 38 \pm 3$ vs. $183 \pm 11 / 39 \pm 3)$ and furcae $(213 \pm 15 / 22 \pm 3$ vs. $180 \pm 10 / 23 \pm 3)$. In Santos, São Paulo, Brazil Ruiz (1953) described the Cercaria amplicocecata from Australorbis immunis $(=$ B. tenagophila) which is similar to Furcocercaria XIX in the arrangement of spines in the body, the arrangement of penetration gland-cells, number of flame cells (20) and resting position in water. However, the Cercaria amplicocecata differs from Furcocercaria XIX in having more penetration gland-cells (6), fewer transverse rows of spines between anterior organ and ventral sucker (7-8), more caudal bodies (8) and fewer sensory hairs (two pairs) in tail stem, having numerous setae in furcae, smaller body $(187 \pm 15 / 54 \pm 6$ vs. $172 / 43)$, larger tail stem (183 \pm 11 vs. 216$)$ and furcae ( $180 \pm 10$ vs. 328$)$.

\section{Family Strigeidae Railliet, 1919 \\ Furcocercaria V (Figs. 5-7, 14-18) \\ Prevalence: $0.40 \%$ \\ Specimen deposited: accession number CECOAL 12032218}

Description: Measurements based on 25

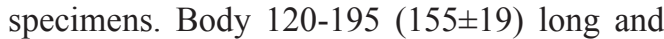
46-96 (56 7 ) wide. Tegument covered with spines, except spineless area ventrally anterior and posterior to ventral sucker. Sensory button papillae distributed on ventral and dorsal surface of body (Figs. 14, 15) and ventral sucker (Fig. 17). One pair of sensory hairs at level of the excretory vesicle. Anterior organ elongate-oval, 32-44 (38 \pm 3$)$ long and 25-39 $(31 \pm 4)$ wide, first third covered with ten rows of spines larger than body spines. Prepharynx shorter than pharynx, pharynx oval, 11-16 

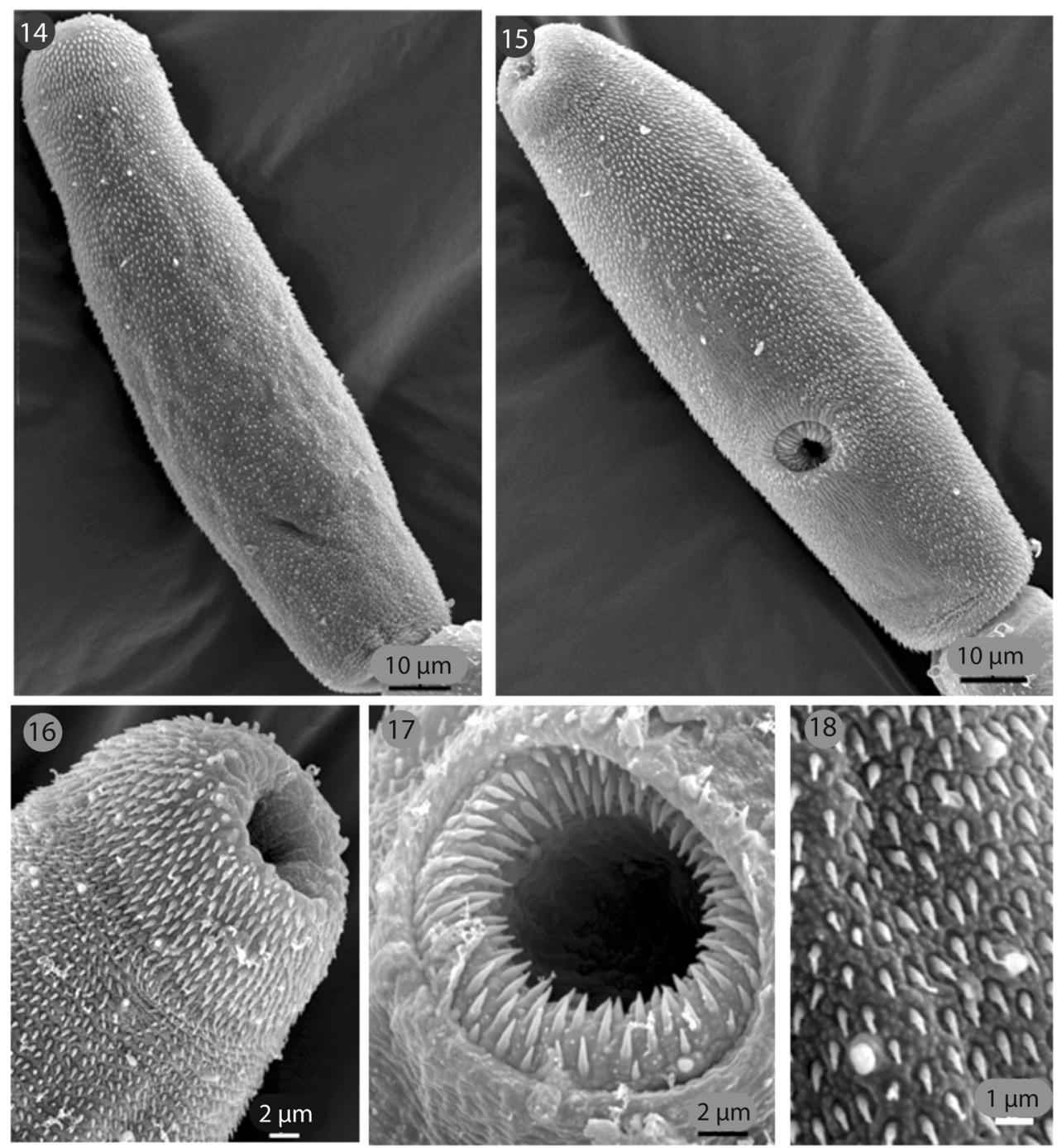

Figs. 14-18. Scanning electron micrographs of Furcocercaria V. 14: dorsal view of cercarial body showing arrangement of sensory button papillae and spines on tegument; 15: ventral view of cercarial body showing arrangement of sensory button papillae and spines on tegument; 16: detail of rows of spines on the anterior organ; 17: ventral sucker with 5 circles of spines surrounding its opening and sensory button papillae above it; 18: detail of spines and sensory button papillae on body.

(14 \pm 2$)$ long and 14-16 (14 \pm 1$)$ wide. Oesophagus shorter than pharynx, intestinal bifurcation in posterior third of forebody; caeca septated, terminate at some distance from excretory vesicle. Colourless eye-spots between level of intestinal bifurcation and ventral sucker. Ventral sucker subspherical, post-equatorial, 20-30 (25 \pm 2$)$ long and 23-30 (26 \pm 2$)$ wide, with five circles of spines surrounding its opening. Two pairs of coarsely granulated penetration gland-cells situated one behind the other, anterior and lateral to ventral sucker. Flame cell formula: $2[(2+2)+(2+2+[2])]=20$, up to three ciliary patches in common collecting ducts. Excretory vesicle small, V-shaped, with round stem. Transverse commissure present anterior to ventral sucker. Caudal excretory duct passes through tail stem, excretory pores somewhat anterior at mid-length of furcae. Tail stem 140-

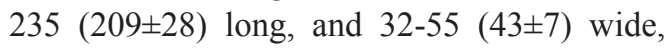


with spines smaller than body spines, and 10-14 pairs of sensory hairs, without caudal bodies. Furcae 154-230 (204 \pm 26$)$ long and 201-34 (27 \pm 5$)$ wide, with spines smaller than tail stem spines.

At resting position, the cercariae maintained themselves suspended in the water with their bodies directed downward, body and tail stem in a straight line and furcae spread at an angle of approximately $90^{\circ}$ (Fig. 7).

Cercariae emerge from sporocysts. In one snail, metacercariae of normal Tetracotyle form were observed encysted in their own sporo-

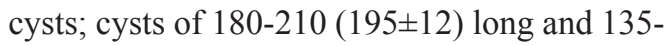
$165(139 \pm 10)$ wide, with thick double wall.

Emergence of cercariae was monitored during two days in two infected snails. At 14.1-27.1 ${ }^{\circ} \mathrm{C}$ cercariae had emergence peaks between 11 am and $3 \mathrm{pm}$.

Remarks: Furcocercaria V shows the typical characteristics of the cercariae of Cotylurus Szidat, 1928 regarding the presence of four penetration gland-cells, colourless eye-spots, 20 flame cells and transverse commissure anterior to ventral sucker, only differ in the arrangement of penetration gland-cells (anterior to ventral sucker) (Niewiadomska, 2002). Three species of this genus have cercariae with features similar to Furcocercaria V, besides those mentioned above. The cercaria of $C$. flabelliformis (Faust, 1917) is similar in having 4-5 circles of spines surrounding the opening of its ventral sucker, as well as in size of the suckers, tail stem and furcae, the resting position and the absence of caudal bodies; but differs from Furcocercaria $\mathrm{V}$ by having larger body (139-231 vs. 120-195), using snails of genus Lymnaea Lamarck, 1799 and Physa Draparnaud, 1801 as first intermediate hosts, and encysting in snails Lymnaea Lamarck, 1799. Cotylurus flabelliformis may also penetrate snails of Planorbidae and Physidae, but only if they are infected by other species of trematodes, where its encysts within sporocysts and/ or rediae (Cort, Olivier, \& Brackett, 1941). The cercaria of C. brevis Dubois \& Rausch, 1950 is similar to Furcocercaria $\mathrm{V}$ in the number and position of sensory hairs in the body (one pair posterior to ventral sucker); but differs in the number of circles of spines (three) surrounding the opening of ventral sucker, the presence of caudal bodies, a larger body (120-360/30-110 vs. 120-195/46-96) and furcae (240-270 vs. 154-230), and by using snails of genus Lymnaea as first intermediate hosts. The cercaria of Cotylurus (Cotylurus) lutzi Basch, 1969 from Biomphalaria glabrata in Bahía, Brazil is similar to Furcocercaria $\mathrm{V}$ in the number of sensory hairs in the tail stem (10-12 pairs) and the hours of emergency (near noon); but differs in having a shorter body (130-174/31-49 vs. $120-195 / 46-96)$, tail stem (115-166/29-39 vs. 140-235/32-55) and furcae (143-174/13-16 vs. 154-230/21-34) and more sensory hairs in the body (five pairs). The cercaria of Cotylurus (Cotylurus) lutzi encysts in ovotestis of molluscs or hyperparasitizes the redia or sporocysts of other trematodes, developing encysted metacercariae of the "tetracotyle" form (Yamaguti, 1975).

In Caratinga, Mina Gerais, Brazil Ruiz (1953) described the Cercaria caratinguensis from Australorbis glabratus $(=$ B. glabrata), which is similar to Furcocercaria V in the presence of colourless eye-spots, sensory hairs in the tail stem, resting position in water, and in having a metacercariae of normal Tetracotyle form encysted in some host analized. However, Cercaria caratinguensis differs from Furcocercaria $\mathrm{V}$ in the number of flame cells (14 vs. 20 ), the presence of caudal bodies in tail stem, a shorter body (129-172/61-70 vs. 120-195/46$96)$, oral sucker (25-40 vs. $32-44)$, tail stem (148-172/37-43 vs. $140-235 / 32-55)$ and furcae (166-191 vs. 154-230). The number of penetration gland-cells was not specified by the author.

\section{Furcocercaria XX (Figs. 8-11) \\ Prevalence: $0.04 \%$ \\ Specimen deposited: accession number CECOAL 12032219}

Description: Measurements based on 20 specimens. Body 99-131 (117 \pm 9$)$ long and 39-53 (45 \pm 4$)$ wide. Tegument covered 
with spines. Three pairs of sensory hairs on lateral margins of body: one pair at level of the anterior organ, one pair anterior to ventral sucker and one pair anterior to excretory vesicle. Anterior organ elongate-oval, 23-37 (30 \pm 3$)$ long and 23-30 (26 \pm 2$)$ wide, first third covered with rows of larger spines. Prepharynx shorter than pharynx, pharynx oval, 9-14 (11 \pm 1$)$ long and 9-11 (10 \pm 1$)$ wide. Oesophagus shorter than pharynx, intestinal bifurcation in posterior third of forebody; caeca terminate fairly close to excretory vesicle. Ventral sucker spherical, post-equatorial, 21-30 (23 \pm 2$)$ long and 18-25 $(23 \pm 2)$ wide, with $2-3$ circles of spines surrounding its opening. Colourless eye-spots, 11 long and 9 wide, at half-length between pharynx and ventral sucker. Eight pairs of coarsely granulated penetration gland-cells, lateral and posterior to ventral sucker. Flame cell formula: $2[(1+1)+(1+1+[1])]=10$. Excretory vesicle small, $\mathrm{V}$-shaped, with round stem. Incomplete transverse commissure anterior to ventral sucker. Caudal excretory duct passes through tail stem, excretory pores in the first third of furcae. Tail stem 115-126 (120 \pm 3$)$ long and 30-41 (34 \pm 3$)$ wide, with six pairs of sensory hairs and three pairs of caudal bodies. Furcae 126-149 (142 \pm 5$)$ long and 11-18 (14 \pm 2$)$ wide, with spines smaller than body spines.

Cercariae emerge from sporocysts. At resting position, cercarial body and tail stem remain aligned in a straight line and furcae spread at an angle of approximately $90^{\circ}$ (Fig. 11).

Remarks: Furcocercaria sp. XX shows similarities to those of genera Strigea Abildgaard, 1790, Apatemon Szidat, 1928, Pharyngostomum Ciurea, 1922 and Parastrigea Szidat, 1928 due to presence of ten flame cells and non-pigmented eyespots; however, the first three genera have fewer penetration gland-cells (4 or 2 pairs). Only Parastrigea has seven pairs of penetration gland-cells lateral and posterior to ventral sucker and anterior excretory commissure, which may not be closed (Niewiadomska, 2002). The adult stages of this genus use birds and exceptionally mammals as definitive hosts (Yamaguti, 1971).
The cercaria of Parastrigea robusta Szidat, 1928 described by Odening $(1965,1966)$ parasitizing Planorbis planorbis (Linnaeus, 1758) and Anisus vortex (Linnaeus, 1758) in Germany, is similar to Furcocercaria $\mathrm{XX}$ in the arrangement of penetration gland-cells, but differs in having fewer penetration gland-cells (seven pairs $P$. robusta vs. eight pairs Furcocercaria XX), more sensory hairs in the body (four pairs vs. three pairs), fewer sensory hairs in the tail stem (four pairs vs. six pairs), more caudal bodies (five pairs vs. three pairs), longer body (155-224/69-93 vs. $99-131 / 39-53)$, tail stem (190-224/38-45 vs. $115-126 / 30-41)$ and furcae (190-207/28-35 vs. 126-149/11-18) and lacking an incomplete transverse commissure.

In Corrientes Province, Argentina, Ostrowski de Núñez et al. (1997) described two cercariae similar to Furcocercaria XX in the number of flame cells (10) and the presence of non-pigmented eyespots: Furcocercaria sp. VIII from $B$. orbignyi and B. peregrina and Furcocercaria sp. XIII from B. tenagophila and B. orbignyi. However, both cercariae differ in having fewer penetration glands (4 pairs) and lacking an incomplete transverse commissure.

\section{DISCUSSION}

Cercariae of two species of the family Strigeidae (Furcocercaria V, Furcocercaria XX) and one of the family Diplostomidae (Furcocercaria XIX) were found in a rice field in Corrientes, Argentina. This species are added to the eight cercariae previously reported parasitizing $B$. straminea in the same environment (Fernández et al. 2013, 2014), and are new records of cercariae from Argentina.

The furcocercariae identity to genus level cannot be elucidated because the arrangement (Furcocercaria XIX and Furcocercaria $\mathrm{V})$ and the number of penetration gland-cells (Furcocercaria XX) did not match with any species known. However, according to the characteristics of the families to which the cercariae described are tentatively assigned, theirs potential definitive hosts would be mainly aquatic birds. In this sense, the rice fields 
in Northeastern Argentina harbor numerous species of aquatic birds that use these environments as refuge, food sources and breeding sites (Blanco et al., 2006; Blanco \& de la Balze, 2011). Thus, many of these bird species might act as definitive hosts in the life cycles of theses trematodes that are found as larvae parasitizing snails. Furthermore, the positive results of experimental infections of Furcocercaria XIX in fish, suggest that its second intermediate host should be found among these aquatic vertebrates, which are part of the diet of several bird species present in this agricultural environment.

In general terms, the prevalence of the different furcocercariae was low, and regarding the rice cultivation cycles, it was somewhat higher in the second rice cultivation cycle. Similar results were previously observed in the same rice field (Fernández et al., 2014), and this could be related to diverse factors, such as the presence of greater numbers of definitive hosts in the environment during the second rice cultivation cycle, or fewer snails in the environment during the same period.

The study of the freshwater species in rice fields is important because it can contribute to the conservation of biodiversity in regions where wetlands have been turned into rice fields (Maltchik et al. 2011). In this sense, given the importance of this agroecosystem type in Northeast Argentina, further research efforts should be encouraged to obtain more knowledge about the larval trematode species that parasitize snails in rice fields (using morphological, molecular and life-cycle data) as well as of their hosts.

\section{ACKNOWLEDGMENTS}

We would like to thank the authorities of the Agricultural Experimental Station El Sombrero, Corrientes of Instituto Nacional de Tecnología Agropecuaria (INTA) for allowing access to the rice field and for providing accommodation during the sampling period. We thank Margarita Ostrowski de Núñez for reviewing a draft version of the manuscript and making useful suggestions and to two anonymous referees, who helped to improve the manuscript. This study was funded by the Consejo Nacional de Investigaciones Científicas y Técnicas (CONICET), Argentina.

\section{RESUMEN}

Cercarias (Orden: Strigeidae, Diplostomidae) en Biomphalaria straminea (Planorbidae) de un campo de arroz en el Nordeste Argentino. Los campos de arroz pueden proporcionar hábitats para muchas especies de invertebrados acuáticos, como insectos, moluscos, crustáceos; y vertebrados, como peces, anfibios, reptiles y aves, los cuales pueden actuar como hospedadores en los ciclos de vida de los parásitos digeneos. En este contexto, el objetivo del presente estudio fue describir las cercarias encontradas en Biomphalaria straminea de un campo de arroz en el Nordeste Argentino. Este caracol de agua dulce habita una amplia variedad de ambientes, principalmente cuerpos de agua superficiales, estancados o de flujo lento. Para este estudio, los caracoles fueron recolectados de las parcelas cultivadas y los canales de riego durante los periodos de inundación (desde la siembra hasta poco después de la cosecha del arroz) entre diciembre 2010 y Mayo 2011 y Diciembre 2011 y Abril 2012, en un campo de arroz de la provincia de Corrientes, una de las principales productoras de arroz de Argentina. Un total de 5510 caracoles fueron examinados de los cuales 26 estuvieron infectados con tres trematodes larvales pertenecientes a Strigeidae, Furcocercaria V (0.40 \%) y Furcocercaria XX (0.04 \%), y Diplostomidae, Furcocercaria XIX (0.04 \%). Furcocercaria XX y Furcocercaria XIX estuvieron presentes en un ciclo de cultivo de arroz, mientras que Furcocercaria V estuvo presente en ambos ciclos de cultivo. La prevalencia de las diferentes furcocercarias fue algo mayor en el segundo ciclo de cultivo de arroz. Las cercarias descritas son nuevos registros para Argentina que se adicionan a las 53 cercarias previamente registradas para Biomphalaria spp. en diferentes ambientes acuáticos del país. El estudio de digeneos larvales en los campos de arroz es importante porque contribuye al conocimiento de la biodiversidad en estos ambientes.

Palabras clave: Trematoda, caracoles de agua dulce, estados larvales, humedales agrícolas, provincia de Corrientes.

\section{REFERENCES}

ACPA (Asociación Correntina de Plantadores de Arroz). (2014). Relevamiento arrocero nacional. Avance de cosecha: campaña 2013/14.

Bambaradeniya, C. N. B. (2000). Ecology and biodiversity in an irrigated rice field ecosystem in Sri Lanka. 
(Ph.D. Thesis). University of Peradeniya, Peradeniya, Sri Lanka.

Bambaradeniya, C. N. B., \& Amerasinghe, F. P. (2003). Biodiversity associated with the rice field agroecosystem in Asian countries: A brief review. Working Paper 63. Colombo, Sri Lanka: International Water Management Institute.

Blanco, D. E. \& De la Balze, V. M. (2011). Conservación de los recursos acuáticos y de la biodiversidad en arroceras del nordeste de Argentina. Buenos Aires, Argentina: Fundación Humedales/ Wetlands International.

Blanco, D. E., López-Lanús, B., Dias, R. A., Azpiroz, A., \& Rilla, F. (2006). Uso de las arroceras por chorlos y playeros migratorios en el sur de América del Sur. Implicancias de conservación y manejo. Buenos Aires, Argentina: Fundación Humedales/ Wetlands International.

Bush, A. O., Lafferty, K. D., Lotz, J. M., \& Shostak, A. W. (1997). Parasitology meets ecology on its own terms: Margolis et al. revisited. Journal of Parasitology, $83,575-583$

Cort, W., Olivier, L., \& Brackett, S. (1941). The relation of physid and planorbid snails to the life cycle of the strigeid trematode, Cotylurus flabelliformis (Faust, 1917). Journal of Parasitology, 27, 437-448.

Czech, H. A., \& Parsons, K. C. (2002). Agricultural wetlands and waterbirds: a review. Waterbirds, 25, 56-65.

Davies, D., \& Ostrowski de Núñez, M. (2012). The life cycle of Australapatemon magnacetabulum (Digenea: Strigeidae) from Northwestern Argentina. Journal of Parasitology, 98, 778-783.

Davies, D. A. (2014). Digenea (Trematoda, Plathelminthes) parásitos de Biomphalaria spp. en el Valle de Lerma, provincia de Salta. (Ph.D. Thesis). Universidad Nacional de Salta, Salta, Argentina.

Duré, M. I., Kehr, A. I., Schaefer, E. F., \& Marangoni, F. (2008). Diversidad de anfibios en campos de arroz en el noreste de Argentina. Interciencia, 33, 523-527.

Elphick, C. S., Parsons, K. C., Fasola, M., \& Mugica, L. (2010). Ecology and conservation of birds in rice fields: A global review. Waterbirds, 33 (Special Publication No. 1).

Fernández, M. V., Hamann, M. I., \& Ostrowski de Núñez, M. (2013). Larval trematodes from Biomphalaria straminea (Mollusca, Planorbidae) in a rice field in Corrientes Province, Argentina. Revista Mexicana de Biodiversidad, 84, 756-764.

Fernández, M. V., Hamann, M. I., \& Ostrowski de Núñez, M. (2014). Echinostome cercariae from Biomphalaria straminea (Mollusca, Planorbidae) in a rice field from Northeastern Argentina. Revista Mexicana de Biodiversidad, 85, 1024-1031.

Fernández, M. V., Hamann, M. I., \& Ostrowski de Núñez, M. (2016). New larval trematodes in Biomphalaria species (Planorbidae) from Northeastern Argentina. Acta Parasitologica, 61, 471-492.

Flores, V., \& Brugni, N. (2005). Notocotylus biomphalariae n. sp. (Digenea: Notocotylidae) from Biomphalaria peregrina (Gasteropoda: Pulmonata) in Patagonia, Argentina. Systematic Parasitology, 61, 207-214.

Hugghins, E. J. (1954). Life hstory of a strigeid trematode Hysteromorpha triloba (Rudolphi, 1819) Lutz, 1931. II Sporocyst through adult. Transactions of American Microscopical Society, 73, 221-236.

Machado, I. F., \& Maltchik, L. (2010). Can management practices in rice fields contribute to amphibian conservation in southern Brazilian wetlands? Aquatic Conservation: Marine and Freshwater Ecosystems, 20, 39-46.

Maltchik, L., Rolon, A. S., Stenert, C., Machado, I. F., \& Rocha, O. (2011). Can rice field channels contribute to biodiversity conservation in Southern Brazilian wetlands? Revista de Biolología Tropical, $54,1895-1914$.

Manley, S. W. (2008). Conservation in ricelands of North America. Stuttgart, Arkansas, USA: The Rice Foundation.

Martorelli, S. R., Alda, M. P., Marcotegui, P. S., La Sala, L. F., \& Montes, M. M. (2013). Larval digeneans in Biomphalaria snails from the Salto Grande Dam in the Uruguay River. Publication of the Laboratory of Helminth Parasites and Shellfish. Available in Repository of UNLP SEDICI.

Morris, M. R. (1976). Contribución al conocimiento del parasitismo de Biomphalaria peregrina (D'Orbignyi) (Moll. Gasteropoda). Neotropica, 22, 93-98.

Niewiadomska, K. (2002). Family Strigeidae Railliet, 1919. In D. I. Gibson, A. Jones, \& R. A. Bray (Eds.), Keys to the Trematoda (pp. 231-242). London, UK: CABI Publishing and The Natural History Museum.

Niewiadomska, K. (2005). Family Diplostomidae Poirier, 1886. In D. I. Gibson, A. Jones, \& R. A. Bray (Eds.), Keys to the Trematoda (pp. 167-196). London, UK: CABI Publishing and The Natural History Museum.

Núñez, V., Gutierrez Gregoric, D. E., \& Rumi, A. (2010). Freshwater gastropod provinces from Argentina. Malacologia, 53, 47-60.

Odening, K. (1965). Life cycle of Parastrigea robusta Szidat, 1928 (Trematoda, Strigeida) around Berlin. Z Parasitenkd, 26, 185-96. 
Odening, K. (1966). Die Lebenszyklen der Ententrematoden Parastrigea robusta and Catatropis verrucosa im Raum Berlin. Monatshefte fuer Veterinaermedizin, 17, 663-667.

Odening, K. (1971). Perspektiven der Cercarienforschung. Parasitologische Schriftenreihe, 21, 11-205.

Ostrowski de Núñez, M. (1972). Fauna de agua dulce de la República Argentina. I Anotaciones sobre furcocercarias. Neotropica, 18, 137-140.

Ostrowski de Núñez, M. (1974a). Sobre el ciclo biológico de Episthmium suspensum (Braun, 1901) Travassos 1922. Revista del Museo Argentino de Ciencias Naturales „Bernardino Rivadavia“, 1, 153-164.

Ostrowski de Núñez, M. (1974b). Fauna de agua dulce de la República Argentina. III. Cercarias de la superfamilia Plagiorchioidea (Trematoda). Neotropica, 20, 67-72.

Ostrowski de Núñez, M. (1976). Sobre el ciclo de vida de Hippocrepis fuelleborni Travassos y Vogelsang, 1930 (Trematoda, Notocotylidae). Physis, 35, 125-130.

Ostrowski de Núñez, M. (1977). Fauna de agua dulce de la República Argentina. VIII. Furcocercarias (Trematoda) nuevas de moluscos de las familias Planorbidae y Ancylidae. Physis, 37, 117-125.

Ostrowski de Núñez, M. (1981). Fauna de Agua Dulce de la República Argentina. X. Cercarias de las superfamilias Echinostomatoidea, Allocreadioidea y Microphaloidea (Trematoda, Digenea). Comunicaciones del Museo Argentino de Ciencias Naturales B. Rivadavia, Parasitología, 2, 1-9.

Ostrowski de Núñez, M., Davies, D., \& Spatz, L. (2011). The life cycle of Zygocotyle lunata (Trematoda, Paramphistomoidea) in the subtropical region of South America. Revista Mexicana de Biodiversidad, $82,581-588$.

Ostrowski de Núñez, M., Hamann, M. I., \& Rumi, A. (1990). Larval trematodes of Schistosoma mansoni transmiting snail: Biomphalaria spp. in northeastern Argentina. Acta Parasitologica Polonica, 35, 85-96.

Ostrowski de Núñez, M., Hamann, M. I. \& Rumi, A. (1991). Population dynamics of planorbid snail from a lenitic biotope in Northeastern Argentina. Larval trematodes of Biomphalaria occidentalis and analysis of their prevalence and seasonality. Acta Parasitologica Polonica, 36, 159-166.
Ostrowski de Núñez, M., Hamann, M. I., \& Rumi, A. (1997). Estudio de trematodes larvales en Biomphalaria spp. (Mollusca, Planorbidae) de la localidad de San Roque, provincia de Corrientes, Argentina. Physis, 54, 7-15.

Pinto, H. A. (2013). Biologia e taxonomia de trematódeos transmitidos por moluscos dulciaquicolas na represa da Pampulha, Belo Horizonte, Minas Gerais, Brasil. (PhD. Thesis). Universidade Federal de Minas Gerais, Instituto de Ciências Biológicas Belo Horizonte, Brazil.

Ruiz, J. M. (1953). Contribuição ao estudo das formas larvárias de trematódeos brasileiros. 5 - descrição de três furcocercárias que ocorrem em planorbídeos hospedeiros do Schistosoma mansoni. Memorias do Instituto Butantan, 25, 77-89.

Rumi, A., \& Hamann, M. I. (1990). Potential schistosomevector snails and asssociated trematodes in rice fields of Corrientes, Argentina. Preliminary results. Memórias do Instituto Oswaldo Cruz, 85, 321-328.

Rumi, A., \& Núñez, V. (2013). Gasterópodos continentales de importancia sanitaria en el nordeste argentino. In O. D. Salomón \& A. Rumi (Eds.), Moluscos de interés sanitario en la Argentina (pp. 7-39). Puerto Iguazú, Misiones, Argentina: Ministerio de Salud de la Nación-INMeT.

Stenert, C., Bacca, R. C., Maltchik, L., \& Rocha, O. (2009). Can hydrologic management practices of rice fields contribute to macroinvertebrate conservation in southern Brazil wetlands? Hydrobiologia, $635,339-350$.

Szidat, L. (1951). Cercarias schistosomicas y dermatitis schistosomica humana en la República Argentina. Comunicaciones Museo Argentino de Ciencias Naturales Zoología, 2, 129-150.

Szidat, L., \& de Szidat, C. (1960). Eine neue Dermatitiserregende Cercarie der Trematoden Familie Schistosomatidae aus Tropicorbis peregrinus (d'Orbigny) des Río Quequén. Z. f. Parasitenkunde, 20, 359-367.

Yamaguti, S. (1971). Synopsis of digenetic trematodes of vertebrates. Tokyo, Japan: Keigaku Publishing Co.

Yamaguti, S. (1975). A synoptical review of life histories of digenetic trematodes of vertebrates. Tokyo, Japan: Keigaku Publishing Co. 
